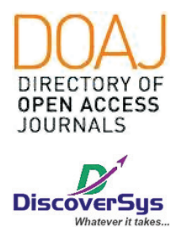

Published by DiscoverSys

\section{Hubungan kadar TNF-a dengan HOMA-IR pada pasien diabetes mellitus tipe-2 di Rumah Sakit Umum Pusat Haji Adam Malik, Medan, Indonesia}

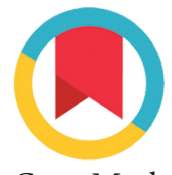

CrossMark

\author{
Poltak, ${ }^{1 *}$ Santi Syafril, ${ }^{2}$ Ratna Akbari Ganie ${ }^{3}$
}

\section{ABSTRACT}

Background: The homeostatic assessment (HOMA) of the first cell- $\beta$ (B) and insulin (IR) function is used to determine insulin sensitivity and cell- $\beta$ function of insulin plasma concentrations and fasting glucose. High extracellular glucose levels will trigger an increase in ROS production (which in turn will increase the formation of Reactive Oxygen Species) expression of TNF a (Tumor Necrosis Factor-a) and exacerbate oxidative stress. The study aimed to determine the relationship between TNF $a$ and HOMA-IR in type 2 DM.

Method: A cross sectional study was conducted at the $\mathrm{H}$. Adam Malik General Hospital Medan from December-February 2018 in 43 patients with type 2 DM. Fasting insulin levels were examined using Celuminescence Microparticle Immunoassay and fasting glucose levels with Enzymatic and TNF a methods with the Elisa method. The relationship of the characteristics of TNF a levels with HOMA-IR in type 2 DM using the Kolmogorov Smirnov test used the Spearman's rank correlation test with SPSS version 20 for windows.

Results: The total sample was 43 samples of patients with type 2 diabetes mellitus. Most of the respondents were male (62.8\%) and had a median age of 57 (39-87) years. In this study, the TNF-alpha levels were $87.28(18.43-846.05) \mathrm{pg} / \mathrm{ml}$. While the H0MA-IR level was 3.36 (0.41-25.82). There was no significant correlation between serum TNF a levels and HOMA-IR in type 2 DM patients ( $P>0.05$ ).

Conclusion: There is no significant relationship between TNF a levels and HOMA-IR in type 2 DM patients.

Keywords : Type 2 DM, HOMA-IR, TNF a.

Cite This Article: Poltak, Syafril,S., Ganie, R.A. 2019. Hubungan kadar TNF-a dengan HOMA-IR pada pasien diabetes mellitus tipe-2 di Rumah Sakit Umum Pusat Haji Adam Malik, Medan, Indonesia. Intisari Sains Medis 10(3): 580-585. D0I: 10.15562/ism.v10i3.467

\title{
ABSTRAK
}

Latar Belakang: Penilaian homeostatik (HOMA) dari fungsi sel- $\beta$ (B) dan resistensi insulin (IR) digunakan untuk mengetahui sensitivitas insulin dan fungsi sel- $\beta$ dari konsentrasi plasma insulin dan glukosa puasa. Tingginya kadar glukosa ekstraseluler akan mencetuskan peningkatan produksi ROS (yang pada akhirnya akan meningkatkan pembentukan Reactive Oxygen Species) ekspresi TNF a (Tumor Necrosis Factor-a) dan memperparah stres oksidatif. Tujuan penelitian untuk mengetahui hubungan kadar TNF a dengan HOMA-IR pada DM tipe 2. Metode: Penelitian menggunakan desain potong lintang dilakukan di RSUP H. Adam Malik Medan dari Desember-februari 2018 pada 43 penderiita DM tipe 2. Kadar Insulin puasa diperiksa menggunakan Celuminescence Microparticle Immunoassay dan Kadar gulokosa puasa dengan metode Enzimatik dan TNF a dengan metode Elisa. Hubungan karakteristik kadar TNF a dengan HOMA-IR pada DM tipe 2 menggunakan uji Kolmogrov smirnov menngunakan uji korelasi Spearmans rank dengan SPSS versi 20 untuk Windows.

Hasil: Total sampel sebanyak 43 sampel penderita DM tipe 2. Sebagian besar responden berjenis kelamin laki-laki $(62,8 \%)$ dan memiliki nilai median usia 57 (39-87) tahun. Pada penelitian ini diperoleh kadar TNF Alpha adalah 87,28 (18,43-846,05) pq/ml. Sedangkan kadar HOMA-IR adalah 3,36 (0,41-25,82). Tidak dijumpai hubungan bermakna antara kadar serum TNF a dengan HOMA-IR pada pasien DM tipe $2(P>0,05)$. Kesimpulan:Tidak terdapat hubungan bermakna kadar TNF a dengan HOMA-IR pada pasien DM tipe 2 .
Patologi Klinik, Fakultas Kedokteran Universitas Sumatera Utara/RSUP Haji Adam Malik Medan, Indonesia

\section{*Korespondensi:}

Poltak; Departemen Patologi Klinik, Fakultas Kedokteran Universitas Sumatera Utara/RSUP Haji Adam Malik Medan, Indonesia; poltak.nbb@gmail.com

Diterima: 28-03-2019

Disetujui: 16-08-2019

Diterbitkan: 01-12-2019
Kata Kunci : DM tipe 2, HOMA-IR, TNF a.

Cite This Article: Poltak, Syafril,S., Ganie, R.A. 2019. Hubungan kadar TNF-a dengan HOMA-IR pada pasien diabetes mellitus tipe-2 di Rumah Sakit Umum Pusat Haji Adam Malik, Medan, Indonesia. Intisari Sains Medis 10(3): 580-585. D0I: 10.15562/ism.v10i3.467

\section{PENDAHULUAN}

Hiperglikemia adalah suatu kondisi medik berupa peningkatan kadar glukosa dalam darah melebihi batas normal. ${ }^{1}$ Hiperglikemia merupakan salah satu tanda khas penyakit diabetes mellitus (DM), meskipun juga mungkin didapatkan pada beberapa keadaan yang lain. Saat ini penelitian epidemiologi menunjukkan adanya kecenderungan peningkatan angka insidensi dan prevalensi DM tipe-2 di berbagai penjuru dunia. World Health Organization (WHO) memprediksi adanya peningkatan jumlah 
penyandang DM yang menjadi salah satu ancaman kesehatan global. ${ }^{1,2}$

Pada DM tipe 2 ditandai dengan hiperglikemia, yang dapat mengakibatkan terjadinya suatu inflamasi akan merangsang respon imun non spesifik sehingga makrofag akan teraktifasi untuk mengeluarkan sitokin proinflamasi TNF Alpa (Tumor Necrosis Factor- $\alpha) \cdot{ }^{3}$ Kadar TNF Alpa yang tinggi pada penderita DM tipe 2 ini bisa menyebabkan semakin parah resistensi insulin sehingga terjadi disfungsi endotel yang berakibat timbulnya komplikasi penyakit seperti kebutaan, kerusakan ginjal, stroke, amputasi, dan lain-lain. ${ }^{3}$

Rasio glukosa/insulin (G/I ratio) menjadi popular digunakan sejak pertama sekali diperkenalkan pada tahun 1998 karena dianggap lebih akurat mengukur sensitivitas insulin pada wanita dengan PCOS (Polycystic Ovary Syndrome). Inilah yang kemudian dikenal dengan HOMA IR (Hemostatis Model Assesment Insulin Resistence). Rasio glukosa dan insulin ini relatif mudah dihitung. HOMA IR telah dipakai secara luas pada penelitian. Cut-off untuk HOMA IR adalah 2,6. ${ }^{4}$ Resistensi insulin akan meningkat bila HOMA IR lebih besar dari nilai cut off tersebut. Hasil HOMA IR didapati berkorelasi baik dan telah sering digunakan untuk menilai sensitivitas insulin setelah pengobatan. ${ }^{4}$

Penilaian homeostatik (HOMA) dari fungsi sel- $\beta$ (B) dan resistensi insulin (IR) pertama ditemukan tahun 1985. Model HOMA digunakan untuk mengetahui sensitivitas insulin dan fungsi sel- $\beta$ dari konsentrasi plasma insulin dan glukosa puasa. ${ }^{5}$ Hubungan antara glukosa dan insulin pada status basal menunjukkan keseimbangan antara pengeluaran glukosa hepatik dan sekresi insulin, yang ditingkatkan oleh lengkung umpan balik (feedback loop) antara hati dan sel- $\beta .{ }^{5}$

Tingginya kadar glukosa ekstraseluler akan mencetuskan peningkatan produksi ROS (Reactive Oxygen Species) yang pada akhirnya akan meningkatkan pembentukan ekspresi TNF Alpa (Tumor Necrosis Factor- $\alpha$ ) dan memperparah stres oksidatif. ${ }^{6}$ TNF Alpa dapat mengakibatkan resistensi penurunan sensitivitas insulin melalui penurunan autofosforilasi dari reseptor insulin subrat menjadi inhibitor insulin receptor tyrosine kinase activity, penurunan insulin sensitive glucose transporter (GLUT), meningkatkan sirkulasi asam lemak, merubah fungsi sel $\beta$, meningkatkan kadar gliserida dan menurunkan kadar HDL. Mediator proinflamasi dari jaringan adipose yakni TNF- $\alpha$ berkontribusi secara langsung terhadap kerusakan vaskuler, resistensi insulin, dan aterogenesis. ${ }^{6}$

Berkaitan dengan latar belakang yang telah dipaparkan sebelumnya, maka penelitian ini bertujuan untuk mencari tahu hubungan antara kadar TNF- $\alpha$ dengan HOMA-IR pada pasien diabetes mellitus tipe-2 di Rumah Sakit Umum Pusat Haji Adam Malik, Medan, Indonesia.

\section{METODE}

Penelitian ini bersifat potong lintang dilakukan di RSUP H. Adam Malik Medan dari Desemberfebruari 2018 pada 43 penderita DM tipe 2. Kadar Insulin puasa diperiksa menggunakan Celuminescence Microparticle Immunoassay dan Kadar gulokosa puasa dengan metode Enzimatik dan TNF a dengan metode Elisa. Populasi target pada penelitian ini adalah Penderita DM Tipe 2 yang berobat ke RSUP. H. Adam Malik Medan yang memenuhi kriteria inklusi. Kriteria Inklusi pada penelitian ini adalah: 1) Penderita DM Tipe 2 yang berobat ke Divisi Endokrinologi SMF Penyakit Dalam RSUP. H. Adam Malik Medan dan 2) Berusia minimal 18 tahun. Sedangkan kriteria Eksklusi pada penelitian ini adalah: 1) Pasien dengan kehamilan; 2) Pasien dengan penyakit autoimun; 3) Menderita infeksi; dan 4) Merokok

Penderita DM Tipe 2 adalah penderita Diabetes Mellitus yang datang berobat ke SMF Penyakit Dalam RSUP Haji Adam Malik Medan dengan gejala klinis yang sesuai. Telah dilakukan pemeriksaan dan ditegakkan sebagai DM Tipe 2 dengan kriteria Perkeni 2015. Dengan nilai normal Glukosa Darah puasa $>126 \mathrm{mg} / \mathrm{dl}$, Glukosa Plasma 2 jam setelah TTGO > $200 \mathrm{mg} / \mathrm{dl}$,dan HbAlc $>6,5$. Penelitian ini dilaksanakan setelah mendapat izin dari Komite Etik Penelitian Kesehatan Fakultas Kedokteran Universitas Sumatera Utara.

Bahan pemeriksaan laboratorium adalah serum pasien yang dipakai untuk pemeriksaan insulin puasa dan TNF Alpha. Dilakukan serentak setelah terkumpul sejumlah sampel. Pemeriksaan dilakukan menggunakan alat Architec ci4100 (Abboth, Laboratories). Sampel yang beku dicairkan pada suhu ruang,kemudian disamakan dengan vortex. Pemeriksaan ini berdasarkan Cemiluminescence Microparticle Immunoassay (CMIA), dengan prinsip pemeriksaan $20 \mathrm{ml}$ sampel di inkubasi dengan biotin monoclonal insulin spesifik antibodi dan ruthenium monoclonal insulin spesifik antibodi membentuk ikatan sandwich. Kemudian melalui perantaraan biotin streptavidin komplek antigen antibodi akan terikat pada mikropartikel,adanya magnet membuat mikropartikel melekat pada elektroda dan terjadi proses chemiluminecent.

Analisa data dilakukan menggunakan software SPSS (Statistical Package for Social Sciences, Chicago, IL, USA) versi 20 untuk Windows. Gambaran karakteristik pada subjek penelitian disajikan dalam bentuk tabulasi dan dideskripsikan. Hubungan karakteristik klinis dengan kadar TNF Alpha dipakai uji Kolmogrov smirnov. Korelasi 
kadar TNF Alpha dengan HOMA IR diuji dengan test Spearman rank. Semua uji statistik dengan nilai $\mathrm{p}<0,05$ dianggap bermakna.

\section{HASIL}

Penelitian dilakukan selama 3 bulan sejak Desember 2017 sampai Februari 2018, terhadap 43 pasien DM type 2 yang telah melalui proses inklusi dan eksklusi. Dari 43 orang pasien yang ikut dalam penelitian, 27 orang dari keseluruhan sampel adalah laki - laki (62,8 \%) dan sisanya 16 orang (37,2\%) adalah perempuan. Dari keseluruhan peserta penelitian memiliki median usia 57 tahun. Usia termuda yaitu 39 tahun dan tertua yaitu 87 tahun (Tabel 1).

Sebagian besar responden berjenis kelamin laki-laki $(62,8 \%)$ dan memiliki nilai median usia 57 (39-87) tahun. Pada penelitian ini juga diperoleh kadar minimum TNF Alpha adalah 18,43 pq/ml dan maksimum TNF Alpha 846,05 pg/ml dengan median $87,28 \mathrm{pq} / \mathrm{ml}$. Sedangkan kadar minimum HOMA-IR 0,41 dan maksimum 25,82 dengan median 3,36 (Tabel 1).

Hasil penelitian ini menunjukkan bahwa analisis hubungan antara TNF-alpha dengan HOMA-IR menunjukkan tidak terdapat korelasi yang bermakna $(r=0,089$ dan $\mathrm{p}=0,28)$ (Tabel 2). Akan tetapi, penelitian ini menunjukkan terdapat korelasi kuat yang bermakna antara TNF Alpha dengan berat badan $(r=0,75$ dan $\mathrm{p}=0,001)$ maupun korelasi sedang yang bermakna terhadap kadar HbA1C $(r=0,47$ dan $p=0,001)$. Namun, tidak

Tabel 1 Karakteristik Subjek Penelitian

\begin{tabular}{lcc}
\hline Variabel & $\mathbf{N}(\%)$ & $\begin{array}{c}\text { Median } \\
\text { (Minimum- } \\
\text { Maksimum) }\end{array}$ \\
\hline Jenis Kelamin & & \\
Laki-laki & $27(62,8 \%)$ & \\
$\quad$ Perempuan & $16(37,2 \%)$ & $57(39-87)$ \\
Umur (Tahun) & & $87,28(18,43-846,05)$ \\
TNF-alpha (pg/ml) & & $3,36(0,41-25,82)$ \\
HOMA-IR & & \\
\hline
\end{tabular}

Tabel 2 Analisis Hubungan TNF Alpha dengan HOMA-IR, berat badan, KGD puasa, dan kadar HbA1C

\begin{tabular}{lcc}
\hline Variabel & $\mathbf{r}$ & $\mathbf{p}$ \\
\hline TNF-alpha & & \\
HOMA -IR & 0,089 & 0,28 \\
Berat Badan & 0,75 & $0,001^{*}$ \\
KGD Puasa & 0,09 & 0,28 \\
HbAlc & 0,475 & $0,001^{*}$ \\
\hline
\end{tabular}

"Berbeda secara bermakna apabila nilai $\mathrm{p}<0,05$; $\mathrm{r}=$ koefisian korelasi terdapat hasil korelasi yang bermakna antara TNF Alpha dengan KGD Puasa ( $r=0,09$ dan $p=0,28)$ (Tabel 2).

\section{PEMBAHASAN}

Penelitian ini melibatkan 43 pasien DM tipe 2 yang memenuhi criteria penelitian yang terdiri atas lakilaki 27 orang $(62,8 \%)$ dan perempuan 16 orang $(37,2 \%)$. Dari keseluruhan peserta penelitian memiliki usia termuda yaitu 39 tahun dan tertua yaitu 87 tahun. Usia dan jenis kelamin merupakan salah satu faktor resiko DM tipe 2 yang tidak dapat dimodifikasi. Usia merupakan salah satu karakteristik yang melekat pada host atau penderita.

Pada penelitian ini tidak terdapat hubungan yang signifikan antara TNF Alpha dengan HOMA-IR dengan. Hasil penelitian ini sama dengan hasil penelitian Swaroop dkk dimana tidak terdapat hubungan yang signifikan antara TNF Alpha dengan HOMA-IR $(\mathrm{p}=0,088)$ pada group pertama $(n=20),(p=0,49)$ pada group kedua $(n=23)$ dan $(\mathrm{p}=0,12)$ pada group ketiga $(\mathrm{n}=7) .^{7}$

Studi lain yang dilakukan oleh Fan dkk tahun 2014 telah menyimpulkan bahwa TNF Alpha meningkat sebelum onset diabetes dan peningkatan lebih lanjut tidak terkait dengan resistensi insulin. ${ }^{8}$ Tapi studi oleh Bluher dkk melaporkan tidak ada peran TNF Alpha dalam genesis tahap awal resistensi insulin. ${ }^{9}$ Mereka menghubungkan genesis resistensi insulin terhadap asam lemak non-esterifikasi khususnya. Sedangkan studi oleh Lukic dkk tahun 2016 menunjukkan bahwa pada pasien dengan konsentrasi serum hipertensi TNF Alpha meningkat bersamaan dengan peningkatan konsentrasi insulin, dan HOMA IR. ${ }^{10}$ Tidak ada korelasi yang ditemukan antara resistensi insulin dan TNF Alpha.

Berbeda dengan penelitian Ahmed dkk dimana mereka menemukan bahwa pasien DM tipe 2 terkontrol dan tidak terkontrol akan mengalami peningkatan kadar serum IL-6, TGF- $\beta$, dan TNF Alpha dibandingkan kontrol yang tidak menderita DM tipe $2 .{ }^{11}$ Kadar serum IL-6, TGF- $\beta$, dan TNF- $\alpha$ pada pasien DM tipe 2 tidak terkontrol lebih tinggi dibandingkan dengan pasien DM tipe 2 terkontrol. Dengan tingginya kadar serum IL-6, TGF- $\beta$, dan TNF Alpha akan mempengaruhi resiko akan terjadinya komplikasi diabetes pada pasien DM tipe 2 tidak terkontrol.

Peningkatan kadar TNF Alpha yang lebih tinggi pada penderita DM tipe 2 disebabkan oleh meningkatnya kadar glukosa intrasel sehingga timbul keadaan hiperglikemia. Keadaan hiperglikemia ini mengakibatkan terjadinya suatu inflamasi akan merangsang respon imun non spesifik sehingga makrofag akan teraktifasi untuk mengeluarkan 
sitokin proinflamasi seperti TNF Alpha, IL-1,IL-6 dan IL-8. Sitokin ini bisa menyebabkan resistensi insulin pada DM tipe 2. Pada penelitian ini terdapat hubungan yang bermakna antara TNF Alpha dengan Berat badan $(\mathrm{r}=0,75$ dan $\mathrm{p}=0,001)$. Tidak terdapat hubungan yang signifikan antara TNF Alpha dengan Total KGD Puasa ( $r=0,09$ dan $p=0,28)$. Terdapat hubungan yang signifikan antara TNF Alpha dengan HbAlc dengan $(r=0,47$ dan $\mathrm{p}=0,001$ )

Penelitian sebelumnya telah menunjukkan bahwa obesitas dan peningkatan berat badan sangat terkait dengan resistensi insulin, dan obesitas dianggap sebagai faktor risiko paling penting untuk diabetes mellitus tipe 2 selain dari predisposisi genetik. Meskipun dasar molekuler dari hubungan antara obesitas dan diabetes tipe 2 masih kurang dipahami, TNF Alpha yang diproduksi oleh adipocytes telah memainkan peran kunci dalam resistensi insulin obesitas dan dapat berkontribusi untuk terjadinya diabetes tipe 2 . Menurut penelitian Bertin dkk tahun 2015 mendeteksi korelasi antara TNF Alpha dan BMI dengan indikasi adanya jaringan lemak intra-abdomen, tetapi tidak dengan glikemia atau jumlah total massa lemak dalam tubuh. ${ }^{12}$ Sedangkan penelitian Mishima dkk tahun 2014 menemukan bahwa konsentrasi serum TNF pada orang gemuk dengan diabetes melitus tipe 2 tergantung pada resistensi insulin mereka tetapi tidak bergantung pada BMI. ${ }^{13}$

\section{SIMPULAN}

Hasil penelitian ini menunjukkan bahwa tidak terdapat korelasi yang bermakna antara TNF-alpha dengan HOMA-1R dan KGD puasa, namun terdapat korelasi yang bermakna antara TNF-alpha dengan berat badan dan kadar HbA1C. Akan tetapi, masih diiperlukan studi prospektif tambahan dengan populasi yang lebih besar dan pemantauan pasien yang lebih lama sehingga dapat melihat hubungan yang signifikan antara TNF Alpha dengan HOMA IR.

\section{ETIKA PENELITIAN}

Penelitian ini telah mendapatkan persetujuan etik dari komisi etik Fakultas Kedokteran Universitas Sumatera Utara/RSUP Haji Adam Malik Medan, Indonesia sebelum penelitian berjalan.

\section{KONFLIK KEPENTINGAN}

Penulis menyatakan bahwa tidak terdapat konflik kepentingan dalam penulisan hasil laporan penelitian ini

\section{PENDANAAN}

Penulis bertanggung jawab dalam pendanaan penelitian ini tanpa melibatkan pihak sponsor, grant, atau berbagai sumber pendanaan lainnya.

\section{KONTRIBUSI PENULIS}

Seluruh penulis memiliki kontribusi yang sama dalam penyusunan laporan hasil penelitian ini baik selama tahap usulan proposal, pencarian sampel penelitian, analisis data penelitian, hingga interpretasi data penelitian.

\section{DAFTAR PUSTAKA}

1. Forouhi NG, Wareham NJ. Epidemiology of diabetes. Medicine (Abingdon). 2014; 42(12): 698-702

2. Zheng Y, Ley SH, Hu FB. Global aetiology and epidemiology of type 2 diabetes mellitus and its complications. Nat Rev Endocrinol. 2018;14(2):88-98.

3. Yuniarti E. Perbedaan kadar Tumor Necrosis Factor-Alfa antara diabetes mellitus tipe 2 terkontrol dan tidak terkontrol. Bioscience. 2017;1(1):18-29

4. Shepherd PR, Kahn BB. Glucose transporters and insulin action--implications for insulin resistance and diabetes mellitus. N Engl J Med. 1999;22;341(4):248-57.

5. Wallace TM, Levy JC, Matthews DR. Use and abuse of HOMA modeling. Diabetes Care. 2004;27(6):1487-95.

6. Akash MSH, Rehman K, Liaqat A. Tumor Necrosis Factor-Alpha: Role in Development of Insulin Resistance and Pathogenesis of Type 2 Diabetes Mellitus. J Cell Biochem. 2018;119(1):105-110.

7. Swaroop JJ, Rajarajeswari D, Naidu JN. Association of TNF- $\alpha$ with insulin resistance in type 2 diabetes mellitus. Indian J Med Res. 2012;135:127-30.

8. Fan N, Sun H, Wang Y, Zhang L, Xia Z, Peng L et al. Midkine, a potential link between obesity and insulin resistance. PLoS One. 2014 Feb 7;9(2):e88299.

9. Bluher M, Kratzsch J, Paschke R. Plasma levels of tumor necrosis factor alpha, angiotensin II, Growth harmone, and IGF- 1 are not elevated in insulin resistant obese individuals with impaired glucose tolerance. Diabetes Care. 2013;24:328-34.

10. Lukic L, Lalic MN, Rajkovic N, Jotic A, Lalic K, Milicic T, et al. Hypertension in obese type 2 diabetes patients is associated with increases in insulin resistance and il-6 cytokine levels: potential targets for an efficient preventive intervention. Int. J. Environ. Res. Public Health. 2014;11(4):3586-3598

11. Al-Shukaili A, Al-Ghafri S, Al-Marhoobi S, Al-Abri S, Al-Lawati J, Al-Maskari M. Analysis of inflammatory mediators in type 2 diabetes patients.Int J Endocrinol. 2013;2013:976810

12. Bertin E, Nguyen P, Guenounocu M, Durlach V, Potron G, Leutenegger M. Plasma levels of tumor necrosis factor-alpha (TNF-alpha) are essentially dependent on visceral fat amount in type 2 diabetic patients. Diabetes Metab. 2013;26(3):178-82

13. Mishima Y, Kuyama A, Tada A, Takahashi K, Ishioka T, Kibata M. Relationship between tumor necrosis factor-alpha and insulin resistance in obese men with type 2 diabetes mellitus. Diabetes Res Clin Pract. 2014;52(2):119-23.

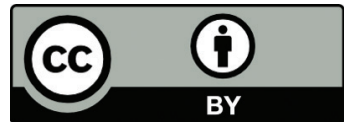

This work is licensed under a Creative Commons Attribution 